\title{
Теряєва Л.А.,
}

викладач музики Університетського коледжу

Київського університету імені Бориса Грінченка,

аспірантка кафедри теорії і методики музичного мистецтва

Iнституту мистеuтв

Київського університету імені Бориса Грінченка

\section{Інноваційні принципи навчання у формуванні методичної компетентності майбутніх учителів музики на заняттях 3 хорового диригування}

Стаття присвячена використанню інноваційних принципів навчання у вивченні дисципліни «Хорове диригування» та їх значенню у формуванні методичної компетентності майбутніх учителів музики. Матеріали проведеного дослідження є базою для внесення коректив до змісту навчальної програми з хорового диригування таї̈ оновлення на основі міждисциплінарних зв'язків хорового диригування із суміжними музичними дисциплінами.

Ключові слова: інновачійні принципи навчання, методична компетентність, хорове диригування, суміжні музичні дисципліни, міждисциплінарні зв'язки, інтенсифікація навчання.

\section{Теряева Л.А.}

Инновационные принципы обучения в формировании методической компетентности будущих учителей музыки на занятиях по хоровому дирижированию

Статья посвящена использованию инновационных принципов обучения в изучении дисциплины «Хоровое дирижирование» и их значению в формировании методической компетентности будущих учителей музыки. Материалы проведенного исследования являются базой для внесения корректив в содержание учебной программы по хоровому дирижированию и ее обновления на основе междисциплинарных связей хорового дирижирования со смежными музыкальными дисциплинами.

Ключевые слова: инновационные принципы обучения, методическая компетентность, хоровое дирижирование, смежные музыкальные дисциплины, междисциплинарные связи, интенсификация обучения.

\section{Teriaeva L.A.}

Innovative Principles for Methodical Competence Formation of Future Music Teachers in Choral Conducting

The article is devoted to the educational process of innovative principles use in the study of discipline "Choral Conducting" and determines their impact on the quality of the training and formation of methodical competence of future music teachers.

The classes in choral conducting with the use of traditional pedagogical principles that are effective and contribute to the consistent and systematic learning, assimilation, and deepen the strength of theoretical knowledge, intellectual and musical development of students. However, modern requirements encourage rethinking of the problems of education quality of future music teachers.

The article examines innovative principles of learning, discloses their content and determines their influence on intensification of educational process and development of future professionals' methodical competence at choral conducting classes.

Incorporation of innovative learning principles into the educational process contributes to the deepening of methodical knowledge intensification and optimization of educational process on choral conducting, the development of interconnection between choral conducting and other musical disciplines, high-quality training of future specialists.

The materials of the research are prerequisite for making adjustments to the content of the curriculum for future music teachers training and updating them on the basis of innovative learning principles.

Key words: innovative principles, methodical competence, choral conducting, related musical discipline, interdisciplinary relations, intensification of training. 
$\Pi$ остановка проблеми. Проблема формування методичної компетентності майбутніх учителів музики на заняттях з хорового диригування $€$ актуальною, але на даний час недостатньо дослідженою особливо в аспекті пошуку нових методик та технологій навчання. Тому необхідно будувати освітній процес у вищих мистецьких навчальних закладах, використовуючи інноваційні принципи навчання, які сприяють підвищенню якості підготовки майбутніх учителів музики, їх залученню до композиторської творчості, застосуванню нових методів і організаційних форм навчання, інтенсифікації навчального процесу і прискоренню формування методичної компетентності.

Аналіз останніх досліджень і публікацій. Дидактичні принципи досліджували А. Алексюк, Ю. Бабанський, I. Бех, В. Беспалько, Г. Ващенко, Й. Гербарт, С. Гончаренко, М. Данилов, А. Дістервег, І. Зязюн, Т. Ільїна, Я. Коменський, В. Краєвський, І. Лернер, Й. Песталоцці, Ж.-Ж. Руссо, М. Скаткін, А. Хуторськой, К. Ушинський та ін. Учені стверджують, що принципи навчання визначають зміст, методи, форми організації навчання і спрямовують діяльність викладача у потрібному напрямку. Але проблема використання інноваційних принципів навчання для формування методичної компетентності майбутніх учителів музики досі не стала об'єктом спеціального дослідження.

Творчому розвитку особистості присвячені наукові праці О. Ростовського, О. Рудницької, Г. Падалки, В. Буцяка, В. Крицького, В. Федоришина, О. Щербініної та ін.; специфіці та методичним підходам до диригентсько-хоровоїпідготовки студентів присвячені дослідження Л. Бірюкової та Лінь Хая.

Метою даної статті $€$ обгрунтування використання у навчальному процесі вищих мистецьких навчальних закладів інноваційних принципів навчання для формування методичної компетентності майбутніх учителів музики при вивченні дисципліни «Хорове диригування».

Завдання статті: уточнення змісту запропонованих інноваційних принципів навчання; визначення ї впливу на інтенсифікацію навчального процесу з хорового диригування і формування методичної компетентності майбутніх фахівців.

Виклад основного матеріалу. На думку О. Олексюк [3], традиційні принципи музичного навчання засновуються на загальних дидактичних принципах, таких як: систематичного та послідовного навчання; усвідомленого засвоєння знань; міцності знань; доступності навчання; наочності навчання; єдності виховання, освіти і розвитку; дидактичний принцип зв'язку навчання $з$ життям.

Для формування методичної компетентності майбутніх учителів музики на заняттях 3 хорового диригування нами пропонується використовувати традиційні принципи навчання, які сприяють послідовному і систематичному навчанню, засвоєнню, поглибленню і міцності теоретичних знань, інтелектуальному і музичному розвитку студентів, а саме: систематичності і послідовності навчання, усвідомленого навчання, мотивації та наочності, міцності знань, зв'язку навчання 3 життям.

Запропоновані традиційні дидактичні принципи $є$ достатньо ефективними, але вимоги сучасної освіти вимагають вирішення існуючих проблем навчання, якісної підготовки майбутніх учителів музики, мобільності і застосування набутих знань, умінь і навичок у будь-якій навчальній ситуації. До сучасних принципів навчання науковці пропонують віднести такі: індивідуального підходу, активності, єдності виховання, освіти і розвитку тощо. Тому пошук дієвих принципів навчання $€$ актуальним і потребує продовження.

Ми пропонуємо застосувати на заняттях 3 хорового диригування інноващійні принципи навчання, які можуть бути покладені в основу інтенсифікації навчального процесу і формування методичної компетентності майбутніх учителів музики, а саме: індивідуалізації, національної ідентичності, наукового пізнання, інтенсифікації навчання, інтерактивного навчання, інноваційної наочності, креативного розвитку, підвищення рівня IT, змагальності, міждисциплінарних зв'язків [5], оптимізації навчального процесу [6].

Розглянемо більш детально деякі інноваційні принципи навчання студентів у диригентськохоровій підготовці.

Приниип індивідуалізації на заняттях з хорового диригування посідає перше місце серед усіх сучасних принципів навчання, тому що здійснюється на основі глибокого вивчення особливостей і можливостей студентів, впливає на креативний розвиток майбутнього учителя музики.

На думку деяких науковців [3], найактивніше впливають на музичний розвиток індивідуальні заняття з фаху, на яких застосовуються різні прийоми впливу та активні методи навчання, адже творчий підхід до розвитку індивідуальності - один з основних у музичній педагогіці.

Принцип індивідуалізації повинен враховувати індивідуальні особливості кожного студента, його музичні здібності і здатність до хорового диригування. Викладач використовує цей принцип для індивідуального добору репертуару 3 хорового диригування, методів, засобів і організаційних форм навчання, творчих, проблемнопошукових і дослідницьких завдань для самостійної роботи майбутнього фахівця.

Приниип інтенсифікацї навчання. У сучасних умовах, коли скорочуються навчальні дисципліни 
та аудиторні години для їх вивчення, актуальною $€$ інтенсифікація навчального процесу за рахунок перегляду навчальних планів і програм навчальних дисциплін, перенесення деяких тем на самостійне опрацювання студентами з обов'язковим проміжним контролем, а також створення нового, інноваційного методичного забезпечення, яке дає додаткові можливості для інтенсифікації навчання.

Розробка такого методичного забезпечення $€$ особливо актуальною і має включати короткі теоретичні відомості, тестові завдання, тематику самостійних робіт, контрольні запитання та відповіді на них, перелік репертуару, музичні додатки з хоровими творами і пісенним шкільним репертуаром. Важливо враховувати і головні фактори інтенсифікації навчального процесу: підвищення цілеспрямованості і поглиблення мотивації навчання, змістовну насиченість дисципліни i прискорення темпу навчання, використання навчально-пізнавальних, проблемно-пошукових і творчих завдань з хорового диригування, застосування сучасних музично-комп'ютерних програм і інформаційно-комп'ютерних технологій.

Приниип інтерактивного навчання. Сучасна система навчання поєднує управління викладача із самостійністю студентів і базується на проблемному навчанні. Викладач спрямовує навчальнопізнавальну діяльність студентів, організовує проблемно-пошукову роботу, мотивує інтерактивне навчання, активізує самостійну роботу майбутніх учителів музики над вдосконаленням методичних компетентностей.

Інтерактивне навчання - це навчання в режимі діалогу, під час якого відбувається залучення майбутніх учителів музики до активної креативної діяльності і творча взаємодія викладача з хорового диригування зі студентами. Виконуючи поставлені педагогом завдання, студент закріплює вивчений матеріал і вивчає новий, передаючи свої знання іншим. Цей принцип робить навчання активним, а процес - більш ефективним.

Приници національної ідентичності сприяє наданню пріоритетного місця у змісті навчання українській народній творчості (фольклору), хоровим творам українських композиторів та їх обробкам народних пісень, творчості сучасних українських авторів і виконавців, сучасній дитячій творчості, репертуару сучасних національних хорових колективів.

Як підкреслює О. Бенч-Шокало, основою української хорової культури є обрядова традиція, яка «зберігається як таїнство душі - життєтворчої сили самого життя, є духовним життям як його праосновою» $[1,2]$, а концепція виконавського фольклоризму, в свою чергу, - основним напрямком для хорової практики.
Чимало досліджень присвячено національній основі музичної освіти. Це наукові роботи Г. Падалки, В. Шульгіної, М. Черепанина, Л. Воєвідко, І. Єгорової, І. Газіної, В. Стрельчука та ін. Дослідники порушують питання модернізації змісту музичної освіти на національній основі, поглибленого вивчення народних традицій і обрядів, творчості сучасних українських авторів.

Для особистісно зорієнтованої мистецької освіти науково значущою стає концепція формування духовного потенціалу молоді, розроблена О. Олексюк [4]. Автор дійшла висновку, що наразі актуальною $є$ проблема створення нової системи народної освіти, яка б базувалася на національнокультурних традиціях і враховувала досягнення вітчизняної і світової науки.

Перегляд і переосмислення історичних етапів розвитку хорового мистецтва та його ролі для духовної і музичної культури студентів, впливу народної творчості на розширення їх світогляду і творчого розвитку свідчить про необхідність розроблення принципів добору хорового навчального матеріалу 3 метою формування у майбутніх учителів музики національної самосвідомості і гідності засобами національного музичного мистецтва.

Одним із важливих завдань сучасної освіти $€$ формування наукового світогляду студентів. Приниип наукового пізнання означає впровадження у навчальний процес сучасних досягнень педагогіки, психології, науково-педагогічних концепцій навчання, інноваційних методик викладання різних музичних дисциплін, зокрема диригентської, вокально-хорової методики, музичних комп'ютерних програм для запису нот i музики. Даний принцип передбачає, що зміст програм знайомитиме студентів 3 найновішими науковими фактами, поняттями, термінами, законами, теоріями і концепціями всіх основних розділів дисциплін музично-теоретичного циклу. Для підвищення методичної підготовки студентів потрібні самостійне опрацювання наукових статей і досліджень, методичних розробок і навчальних посібників з хорового диригування та практики роботи 3 хором, знання сучасних навчальних шкільних програм з музичного мистецтва, оволодіння методикою сучасних музичнокомп'ютерних технологій.

Принцип наукового пізнання, базуючись на наукових ідеях і концепціях з різних музичних дисциплін, об’єднує їх у єдину методологічну навчальну систему, яка сприяє розвитку міждисциплінарних зв'язків між різними музичними дисциплінами i якісній диригентсько-хоровій підготовці майбутніх учителів музики.

Приниип інноваційної наочності. Сучасна музична освіта на всіх рівнях музичного виховання вимагає нових засобів наочності, зокрема, 
використання на заняттях 3 хорового диригування навчальних посібників 3 показом різноманітних диригентських схем, відеопрезентацій, аудіо- та відеозаписів 3 фрагментами виступів відомих хорових колективів, а також застосування комп'ютера, аудіоколонок, синтезатора, CD-дисків, музичних комп'ютерних програм.

Особливо це стосується дисципліни «Хорове диригування». Майбутні вчителі музики на заняттях з хорового диригування переважно вивчають хорові твори під супровід фортепіано, і хорове звучання творів вони можуть тільки уявляти. Таке неповноцінне слухове сприйняття формує неправильні слухові уявлення про особливості тембру кожної хорової партії і вокально-діапазонні можливості хорового колективу, не розкриває творчих можливостей співаків, не готує до практичної роботи з хором і, як наслідок, знижує рівень якісної підготовки майбутніх фахівців.

Принцип інноваційної наочності сприятиме якісному рівню підготовки майбутніх учителів музики, мотивації навчання, розвитку хорознавчого тезауруса, музичної пам'яті, культури мислення, творчої фантазії, набуттю практичного досвіду роботи з хоровим колективом, використанню майбутніми учителями музики різноманітних методичних прийомів і технічних засобів навчання.

Принцип креативного розвитку. Креативний розвиток у диригентсько-хоровій підготовці майбутніх учителів музики - один 3 перспективних шляхів наукових досліджень, де важливу роль відіграють творче сприйняття хорових творів, уявлення й осмислення музичних образів та головної ідеї творів музичного мистецтва, оригінальність у розкритті художнього образу засобами музичної виразності, власна творча ініціатива майбутніх фахівців у диригентській та виконавській діяльності, розвиток їх уяви і фантазії в процесі диригентсько-хорової підготовки, креативне ставлення до виконання творчих завдань з хорового диригування.

Актуальною проблемою освіти $є$ залучення майбутніх учителів музики до композиторської творчості. Велике значення для креативного розвитку мають написані майбутніми учителями музики власні музичні інструментальні та вокальні твори для дітей із застосуванням сучасних музичних комп'ютерних програм. Ці творчі здобутки можуть бути використані майбутніми учителями музики під час проведення уроків музики або гурткової роботи зі школярами у період педагогічної практики.

Приниип підвищення рівня IT передбачає своєчасне та неперервне спостереження майбутніми фахівцями за появою нових музичнокомп'ютерних технологій, музичних комп'ютерних програм, інноваційного програмного забезпечення, а також оновлення навчальних програм з обов'язковим включенням до змісту програми 3 хорового диригування застосування інноваційних технічних засобів, сучасних комп'ютерних музичних програм, інформаційних комп'ютерних технологій, засобів медіа-техніки.

Принии змагальності сприяє змаганню студентів між собою з отриманням відповідної кількості балів за практичні заняття, за виконання самостійної роботи 3 хорового диригування (творчі завдання, реферати, презентаціі), а також додаткових балів з навчальної педагогічної практики за знаходження цікавих сучасних шкільних пісень або творів для хору, написання власних тематичних пісень з інструментальним супроводом 3 використанням музичних комп'ютерних програм для проведення позакласної та гурткової роботи у школі.

Висновки. Проведене дослідження інноваційних принципів навчання показало, що їх впровадження у навчальний процес сприяє поглибленню і узагальненню методичних знань, інтенсифікації і оптимізації навчального процесу 3 хорового диригування, розвитку міждисциплінарних зв'язків між хоровим диригуванням і суміжними музичними дисциплінами, якісній підготовці майбутніх фахівців. Матеріали проведеного дослідження $\epsilon$ передумовою для внесення коректив до змісту робочих навчальних програм 3 підготовки майбутніх учителів музики та їх оновлення на основі інноваційних принципів навчання. Подальше дослідження планується спрямувати на пошук інноваційних методів формування методичної компетентності майбутніх учителів музики, а також оновлення методики викладання хорового диригування та створення комплексу вимог до диригентсько-хорової підготовки майбутніх учителів музики.

\section{ДЖЕРЕЛА}

1. Авдієвський А.Т. Формування особистості на грунті національно-культурного відродження / А.Т. Авдієвський // Мистецтво у школі : зб. ст. / [упоряд. І.М. Гадалова]. - К. : УДПУ, 1996. Вип. І. - С. 80-83.

2. Костенко Л.В. Формування хормейстерських вмінь у класі хорового диригування / Л.В. Костенко, Л.Ю. Шумська. - Ніжин : Вид-во НДПУ ім. М. Гоголя, 2004. - 25 с. 
3. Олексюк О.М. Музична педагогіка : навч. посіб. / О.М. Олексюк. - К. : Київ. ун-т ім. Б. Грінченка, 2013. $-248 \mathrm{c}$.

4. Олексюк О. Педагогіка духовного потенціалу особистості: сфера музичного мистецтва / О. Олексюк, М. Ткач. - К. : Знання України, 2004. - 264 с.

5. Теряєва Л.А. Міждисциплінарні зв'язки у формуванні методичної компетентності майбутніх учителів музики / Л.А. Теряєва // Електронне наукове фахове видання «Освітологічний дискурс» Київського університету імені Бориса Грінченка. - 2015. - Вип. № 2 (10).

6. Теряєва Л.А. Формування методичної компетентності майбутніх учителів музики в процесі диригентсько-хорової підготовки / Л.А. Теряєва // Науковий часопис Національного педагогічного університету імені М.П. Драгоманова. Серія 14: Теорія і методика мистецької освіти : зб. наук. пр. Вип. 17 (22). - К. : НПУ ім. М.П. Драгоманова, 2015. - С. 49-54. 